Original research article

Section: Food Technology

\title{
Behavior of Listeria innocua Strains Under Pressure Treatment - Inactivation and Sublethal Injury
}

\author{
Justyna Nasitowska ${ }^{1 *}$, Barbara Sokotowska ${ }^{1,2}$, Monika Fonberg-Broczek ${ }^{2}$ \\ 'Prof. Wactaw Dabrowski Institute of Agricultural and Food Biotechnology, \\ Department of Fruit and Vegetable Product Technology, 36 Rakowiecka str., 02-532 Warsaw, Poland \\ ${ }^{2}$ Institute of High Pressure Physics, Polish Academy of Sciences, \\ Laboratory of Biological Materials, 29/37 Sokotowska str., 01-142 Warsaw, Poland
}

Key words: Listeria innoсиа, beetroot juice, high hydrostatic pressure, sublethal injury, transmission electron microscopy

The inactivation and sublethal injury of two strains of Listeria innocua (one collection strain and one wild strain isolated from beetroot juice) suspended in beetroot juice and in model solutions, after high hydrostatic pressure (HHP) were investigated. Changes within the population assessed by plating count methods of both L. innoсиa strains suspended in a buffer $\mathrm{pH} 4.0$ were more noticeable than in the natural beetroot juice environment. In beetroot juice the lethal effect was reported after 1 min of pressure treatment at $400 \mathrm{MPa}$ for the collection strain. In the case of the wild type strain, exposure to the maximal parameters of the compression process (400 MPa, $10 \mathrm{~min}$ ) decreased the population number below 1 log $(\mathrm{CFU} / \mathrm{mL})$ but did not cause complete injury. The collection strain of L. innocua was easier to inactivate in beetroot juice than the strain isolated from this environment. The maximum level of sublethal injury was observed when the cells were suspended in a buffer pH 7.0. Structural damage in cell membranes after HHP processing was observed using a transmission electron microscope (TEM).

\section{INTRODUCTION}

Beetroot is a traditional vegetable distributed in many parts of the world and has been used commercially to produce juice and natural pigments. One of the leading red beet producers is Poland, where fresh beetroot juice has nowadays become increasingly popular because of its multiple health benefits, such as anticancer activity and protection against degenerative diseases [Clifford et al., 2015]. Beetroot contains dietary fiber and carbohydrates of a moderate caloric value. It is a rich source of minerals and important vitamins, and therefore it can play an essential role in the composition of a well-balanced diet [USDA Food Composition Database, 2018; Zielińska-Przyjemska et al., 2009]. Due to the fact that edible parts of root vegetables have a direct contact with soil, beetroot juice is one of the most contaminated among the commercially available fresh juices and can be a source of undesirable microbiota including pathogenic microorganisms [Sapers, 2003; Sokołowska et al., 2011]. One of the most virulent foodborne pathogens, widely distributed in the natural environment, is Listeria monocytogenes. It has been detected in fruit and vegetables that are contaminated by the soil or by manure used as a fertilizer. Among the investigated samples of unpasteurized commercial root vegetable and fruit juices, 29\% $(n=17)$ have been reported to contain Listeria

\footnotetext{
* Corresponding Author: Tel.: +48 22606 3605;

E-mail: nasilowska@ibprs.pl (J. Nasiłowska)
}

monocytogenes [Sokołowska et al., 2011]. This pathogen can survive short pasteurization or freezing, and can be resistant to treatment with food preservatives. Moreover, it can grow in acidic foods traditionally considered as of low risk [Jordan et al., 2001]. The infective dose of L. monocytogenes depends on the resistance of the individual host. Fresh fruit and vegetables which are consumed without any further thermal treatment, and are contaminated with $L$. monocytogens at more than $100 \mathrm{CFU} / \mathrm{g}$, are considered to pose a direct risk to human health [Commission Regulation 2073/2005]. Exceeding this number is dangerous, especially for people with compromised immunity, children, the elderly and pregnant women, as it may induce listeriosis and even sepsis [Goulet et al., 2008].

The High Hydrostatic Pressure (HHP) is a technology used worldwide for the preservation of various commercial products, including vegetable juices. However, this technology has not yet been implemented on the industrial scale in Poland. HHP allowed reducing counts of microbes responsible for spoilage and for shortening the shelf-life of beetroot juice [Sokołowska et al., 2013, 2014, 2017], while not markedly changing the sensory and nutritional attributes of the product. Mild, non-thermal technologies used in food preservation, apart from the inactivation, trigger the sublethal injury of bacterial cells. Injury caused by high hydrostatic pressure has been observed in many bacterial cells [Patterson et al., 1995; Yang et al., 2012; Sokołowska et al., 2014; Wang et al., 2016]. The mechanism of microbial inactivation by HHP is re- 
lated to the morphological changes in the cell, modification of the cytoplasmic membrane, damage to the genetic mechanism, and adverse biochemical reaction [Hoover et al., 1989]. Changes in the bacterial cell can be reversible or irreversible depending on the level of environmental stress and physiological condition of the cell. Even though the membrane damage plays a major role in HHP inactivation, the partial loss of its functionality does not always lead to cell death. In a consequence, some of the cells in the population will be sublethally injured [Wesche et al., 2009]. However, the sublethally injured cells may reveal increased sensitivity to inhibitors, which are ingredients of selective agar media [Espina et al., 2016]. The injured survivors are able to recover and resume growth if suitable environmental conditions emerge, and therefore may become dangerous to customers [Mackey et al., 2000]. This is the reason why appropriate identification and quantification of the sublethally injured population play a key role in food safety. An indirect method for evaluating the number of sublethally injured cells is the plating technique which utilizes a selective medium with the addition of $\mathrm{NaCl}$ [Yuste et al., 2004; Sokołowska et al. 2014], because immediately after HHP processing the damaged cells have no, or a lower, ability to grow on this medium.

This work describes results of the investigation of the survival, sublethal injury, and diversity of the resistance of Listeria innocua strains in pasteurized beetroot juice and in model solutions: buffers $\mathrm{pH} 4.0$ and 7.0, after high hydrostatic pressure treatment.

\section{MATERIALS AND METHODS}

\section{Microorganisms and growth conditions}

Listeria innocua was used in this study. This bacteria is physiologically very close to the previously mentioned L. monocytogenes, and is frequently found in the same food products, therefore it is often used for experiments [Escolar et al., 2017].

Two strains of Listeria innocua were used in this study: CIP80.11T obtained from the Culture Collection of the Institut Pasteur (Paris, France) and 23/2013 (wild type strain) isolated from unpasteurized Polish beetroot juice obtained from the own collection of the Department of Fruit and Vegetable Product Technology at IAFB (Warsaw, Poland). The strains were stored in Cryobank at a temperature below $-27^{\circ} \mathrm{C} \pm 3^{\circ} \mathrm{C}$. Broth subcultures were prepared by inoculating a tube containing $10 \mathrm{~mL}$ of sterile Brain Heart Infusion (BHI) broth (BioMerieux, I'Etoile, France) with a pure culture immobilized on sterile beads. After inoculation, the tubes were incubated at $37^{\circ} \mathrm{C}$ for $24 \mathrm{~h}$ and then each overnight culture was moved with a $0.1 \mathrm{~mL}$ loop on a Petri dish with Tryptic Soy Yeast Extract (TSYE) agar (Biocar Diagnostics, Beauvais, France). Next, the culture from the plate with a $0.1 \mathrm{~mL}$ loop was added to $250 \mathrm{~mL}$ Erlenmeyer flasks containing $200 \mathrm{~mL}$ of Tryptic Soy Broth with Yeast Extract (TSBYE) (Biocar Diagnostics, Beauvais, France) to prepare the second subculture, which was incubated at $37^{\circ} \mathrm{C}$ for $18 \mathrm{~h}$ to obtain the stationary phase culture. Then, $10 \mathrm{~mL}$ of the second subculture were added to fresh sterile broth (TSB or TSYEB) and incubated at $37^{\circ} \mathrm{C}$ for $18 \mathrm{~h}$. The cultures were then harvested by centrifugation $\left(4000 \times g, 10 \mathrm{~min}, 4^{\circ} \mathrm{C}\right)$. The sedimented cells were aseptically re-suspended in phosphate-buffered saline (PBS, $\mathrm{pH}$ 7.2) and again centrifuged. The washing procedure was repeated twice. After that, model suspensions of $L$. innocua were prepared in PBS $(1: 9, \mathrm{v} / \mathrm{v})$. Just before HHP treatment, McIlvain buffers ( $0.1 \mathrm{M}$ citric acid, $0.2 \mathrm{M}$ disodium

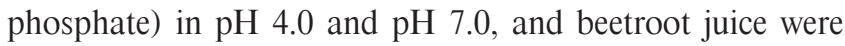
inoculated with L. innocua cells in a concentration of about $10^{7} \mathrm{CFU} / \mathrm{mL}$ and transferred into sterile polyethylene tubes (Sarstedt, Newton, USA) in $13 \mathrm{~mL}$ portions in duplicate.

\section{Model suspensions and beetroot juice}

McIlvaine buffers $\mathrm{pH} 4.0$ and $\mathrm{pH} \mathrm{7.0,} \mathrm{and} \mathrm{pasteurized}$ beetroot juice, acidified with citric acid to $\mathrm{pH}$ from 3.98 to 4.17 (produced by Victoria Cymes, Poland) were used.

\section{HHP treatment}

High pressure treatment was performed using a U 4000/65 device (Unipress, Warsaw, Poland). The apparatus was capable of operating up to $600 \mathrm{MPa}$, at temperatures ranging from $-10^{\circ} \mathrm{C}$ to $+80^{\circ} \mathrm{C}$. The maximum volume of the treatment chamber was $0.95 \mathrm{~L}$. The pressure--transmitting fluid was distilled water and polypropylene glycol $(1: 1, v / v)$. Each two independent samples were treated in two independent cycles. The treatment was performed at pressures of $200 \mathrm{MPa}, 300 \mathrm{MPa}$, and $400 \mathrm{MPa}$, at $20^{\circ} \mathrm{C}$ for 1,5 , and $10 \mathrm{~min}$. Pressure of up to $400 \mathrm{MPa}$ was generated in 70 $80 \mathrm{~s}$ and the release time was $2-4 \mathrm{~s}$. The total process time did not include the come-up and come-down time of pressurization. After the treatment, the samples were removed from the chamber and placed immediately on ice. The control samples were unpressurized.

\section{Plate count analytical methods}

The HHP-treated samples were analyzed immediately after processing. Ten-fold serial dilutions in Tryptone Salt broth (Biokar Dignostics, Beauvais, France) of each sample were prepared. Appropriate dilutions of samples were spread on agars. Counts of total viable cells were determined by spread plate on TSYE agar, while TSYE agar supplemented with 5\% $\mathrm{NaCl}$ (POCh, Gliwice, Poland) was used to determine uninjured cells in the population [Yuste et al., 2004]. This concentration of $\mathrm{NaCl}$ was estimated in the laboratory as the maximum concentration that did not change the morphology and number of unstressed $L$. innocua cells. The number of sublethally injured survivors was estimated by the difference between the counts of total viable and uninjured cells in the population [Yuste et al., 2004; Espina et al., 2016]. Plates with TSYE agar were incubated for $24 \mathrm{~h} / 37^{\circ} \mathrm{C}$, and these with TSYE agar $+5 \% \mathrm{NaCl}$ for $48 \mathrm{~h} / 37^{\circ} \mathrm{C}$ [Espina et al., 2016]. The plates containing less than $300 \mathrm{CFU} / \mathrm{mL}$ were selected for counting [Yuste et al., 2004].

\section{Cell morphology assessment by transmission electron microscopy (TEM)}

After exposure to $400 \mathrm{MPa}$ for $5 \mathrm{~min}$, the bacteria cells in the PBS buffer ( $\mathrm{pH}$ 7.2) were fixed with $2.5 \%$ glutaraldehyde cacodylic buffer and incubated for one hour, then washed with $0.1 \mathrm{M}$ cacodylic buffer. Next, they were postfixed in $1 \% \mathrm{OsO}_{4}$ in $\mathrm{ddH}_{2} \mathrm{O}$ for $1 \mathrm{~h}$ and washed three times in $\mathrm{ddH}_{2} \mathrm{O}$. Af- 
ter postfixation, the samples were dehydrated through a graded series of EtOH (30\% - 10 min, 50\% - 10 min, 70\% - 24 h, 80\% $10 \mathrm{~min}, 90 \%$ - $10 \mathrm{~min}, 96 \%$ - $10 \mathrm{~min}$, anhydrous $\mathrm{EtOH}-10 \mathrm{~min}$, acetone $-10 \mathrm{~min})$ and infiltrated with epon resin in acetone (1:3 $-30 \mathrm{~min}, 1: 1-30 \mathrm{~min}, 3: 1-2 \mathrm{~h}$ ), infused twice for $24 \mathrm{~h}$ in pure epon resin and polymerized at $60^{\circ} \mathrm{C}$ for $24 \mathrm{~h}$. Next, $60 \mathrm{~nm} \mathrm{sec-}$ tions were prepared using RMC ultramicrotome MT-X (RMC Boeckeler Instruments, Tucson, USA), contrasted with uranyl acetate and lead citrate according to Reynolds [1983], and examined on LIBRA 120 electron microscope produced by Zeiss (Oberkochen, Germany). Images were captured with the Slow-Scan CCD camera (Proscan) using EsiVision Pro 3.2 software (Soft Imaging Systems GmbH). Measurements were performed using the analySIS ${ }^{\circledR} 3.0$ image-analytical software (Soft Imaging Systems GmbH, Münster, Germany).

\section{Statistical analysis}

The results of survival and sublethal injuries of bacteria were analyzed by two-way ANOVA statistical model with Scheffe's test using Statistica version 13 (TIBCO Software
Inc., Palo Alto, CA, USA). Statistical comparison was made for results obtained at different times of the process. The differences were considered significant at $\mathrm{p}<0.05$.

\section{RESULTS AND DISCUSSION}

\section{Effect of HHP on bacterial cells}

The results of the experiment showed that the inactivation and injury of L. innocua cells subjected to HHP depended on the origin of the strain, as well as the medium and parameters of the process. Survival rates of the population under the studied conditions and in all media tested are presented in Figures 1-3.

For both strains suspended in beetroot juice, increasing the pressurization time from 1 to 10 min under the pressure of $200 \mathrm{MPa}$ had no significant effect on their survival $(\mathrm{p} \geq 0.05)$ (Figure 1). The maximum reduction was less than $1.1 \mathrm{log}$ $(\mathrm{CFU} / \mathrm{mL})$. A higher reduction was achieved when the pressure was increased up to $300 \mathrm{MPa}$. After 5 min of treatment, the population of the collection strain suspended in beetroot
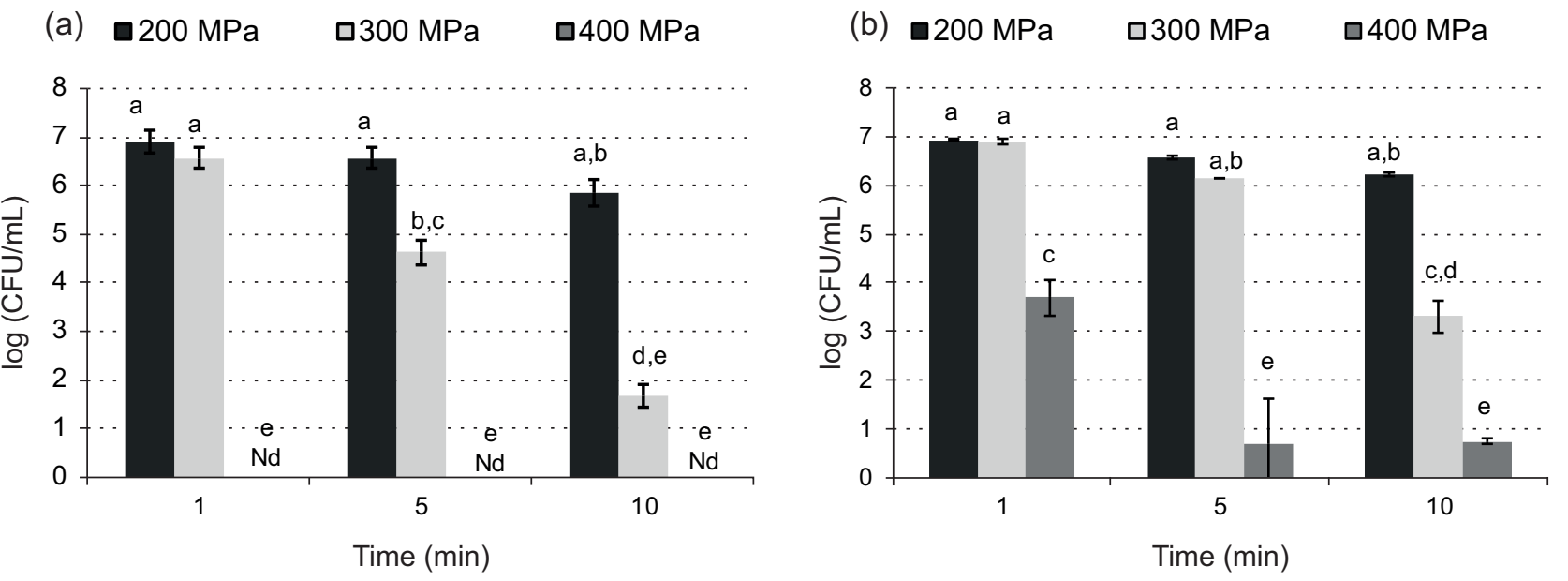

FIGURE 1. Effect of high hydrostatic pressure on the survival of L. innocua CIP80.11T (a) and wild type strain 23/2013 (b) in beetroot juice. The bars with different letters are significantly different at $\mathrm{p}<0.05$; $\mathrm{Nd}-$ not detected.

(a)

-200 MPa

$\square 300 \mathrm{MPa}$

$\square 400 \mathrm{MPa}$

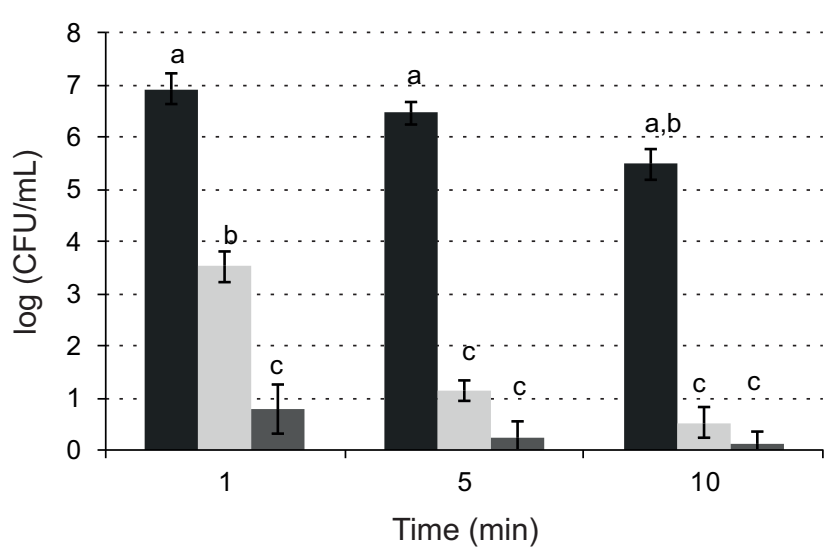

(b) $\quad 200 \mathrm{MPa} \quad \square 300 \mathrm{MPa}$

$\square 400 \mathrm{MPa}$

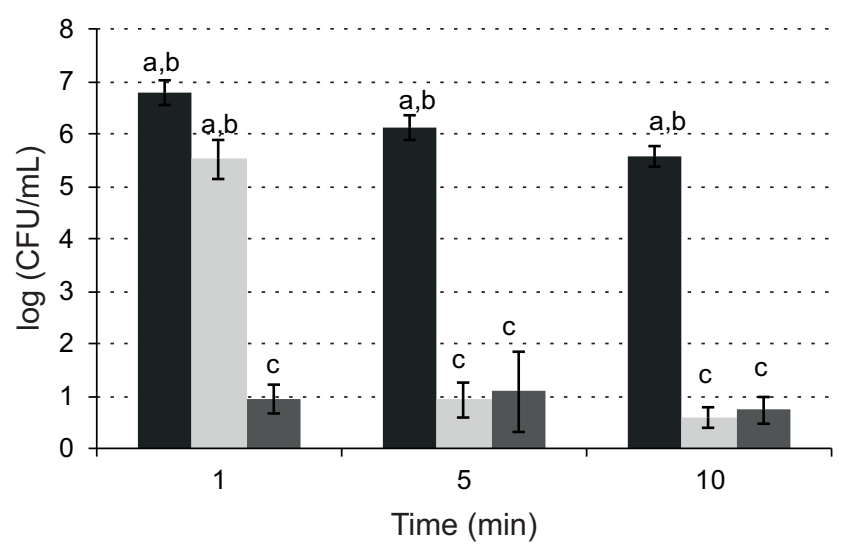

FIGURE 2. Effect of high hydrostatic pressure on the survival of L. innocua CIP80.11T (a) and wild type strain 23/2013 (b) in buffer pH 4 . The bars with different letters are significantly different at $\mathrm{p}<0.05$. 

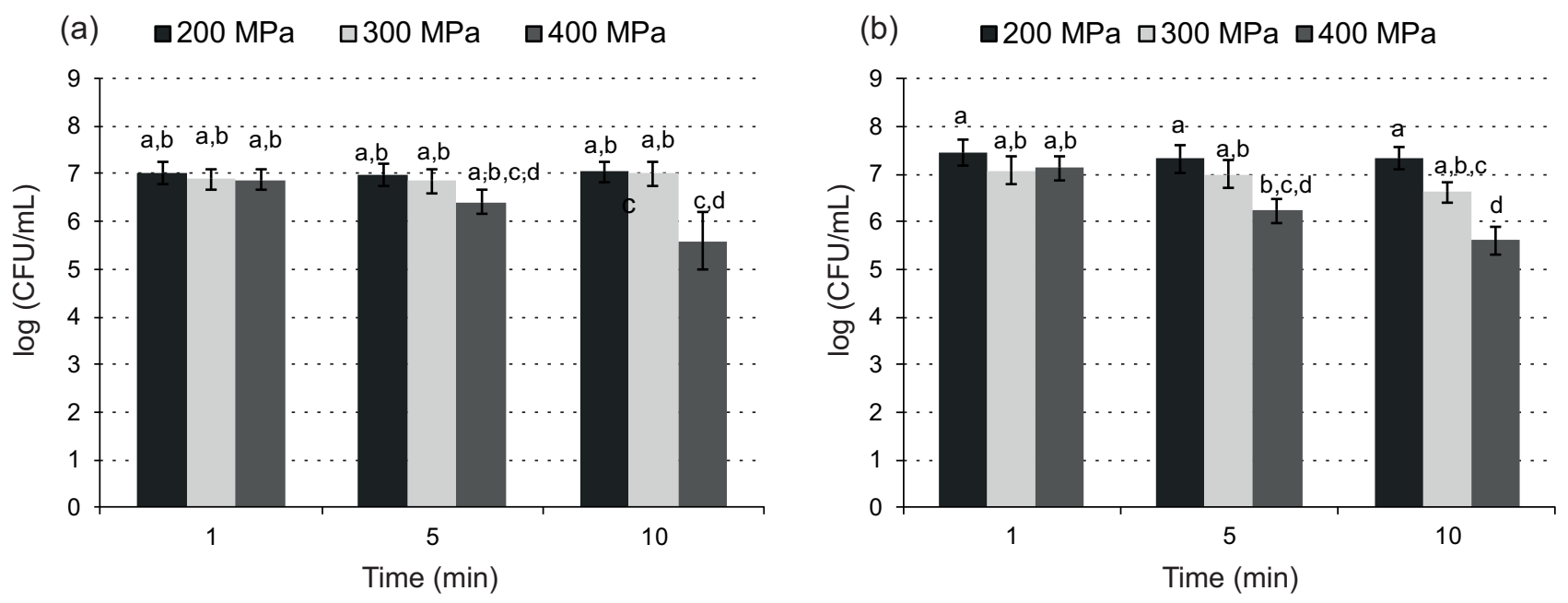

FIGURE 3. Effect of high hydrostatic pressure on the survival of L. innocua CIP80.11T (a) and wild type strain 23/2013 (b) in buffer pH 7. The bars with different letters are significantly different at $\mathrm{p}<0.05$.

juice decreased by $2.3 \log (\mathrm{CFU} / \mathrm{mL})$, while under the same conditions the reduction for the wild type strain was $0.9 \mathrm{log}$ $(\mathrm{CFU} / \mathrm{mL})$. When the treatment time was extended up to $10 \mathrm{~min}$, the inactivation of both strains increased by $2.9 \mathrm{log}$ $(\mathrm{CFU} / \mathrm{mL})$. In the beetroot juice samples, after the application of $400 \mathrm{MPa}$ for $1 \mathrm{~min}$ the collection strain of L. innocua was not detected, while the inactivation of the wild type strain was $3.3 \log (\mathrm{CFU} / \mathrm{mL})$. Increasing the time of exposure up to 10 min resulted in a significant decrease $(p<0.05)$ in the population number of the wild type strain but did not provide its complete inactivation. Our previous studies have shown that the HPP treatment at $400 \mathrm{MPa}$ and $20^{\circ} \mathrm{C}$ for $10 \mathrm{~min}$ of the same beetroot juice $\left(\mathrm{pH} 4.18,{ }^{\circ} \mathrm{Bx} 12.35\right)$, resulted in $6.2 \log (\mathrm{CFU} / \mathrm{mL})$ reduction of E. coli ATCC 7839, whereas HPP treatment at $300 \mathrm{MPa}$ and $20^{\circ} \mathrm{C}$ for 10 min caused about $3.5 \log (\mathrm{CFU} / \mathrm{mL})$ reduction of Saccharomyces cerevisiae NCFB 3191 [Sokołowska et al., 2013, 2014].

Changes within the population of L. innocua suspended in buffer pH 4.0 were more noticeable (Figure 2) than in a natural beetroot juice environment, however there were no significant differences between both strains $(\mathrm{p} \geq 0.05)$. This was most probably due to the presence of molecules, such as lipids and carbohydrates, in product. This modified the effect of HHP on microorganisms, which was confirmed in our previous study [Sokołowska et al., 2013]. After $10 \mathrm{~min}$ of the treatment under $200 \mathrm{MPa}$, the population numbers of the collection and wild type strains decreased by 1.4 and $1.6 \log (\mathrm{CFU} / \mathrm{mL})$, respectively. When the samples of the collection strain in an acid model solution were treated under $300 \mathrm{MPa}$ for $1 \mathrm{~min}$, their inactivation reached $3.3 \mathrm{log}$ $(\mathrm{CFU} / \mathrm{mL})$. Under the same conditions, the level of reduction of the wild type strain was only $1.6 \log (\mathrm{CFU} / \mathrm{mL})$. A decline in the population numbers of both strains at the level of about $1 \log (\mathrm{CFU} / \mathrm{mL})$ was observed after $5 \mathrm{~min}$ of the treatment. Further enhancement of the process parameters had no significant effect on the studied bacterial populations $(\mathrm{p} \geq 0.05)$. Jofré et al. [2010] studied the inactivation of five strains of L. monocytogenes of different origins suspended in a complex medium ( $\mathrm{pH}: 5.1 ; 6.3,7.4)$. The results have demon- strated that treatment at $400 \mathrm{MPa}$ for 10 min greatly affected the viability of each strain. We have shown similar findings in an acid model solution. However, the results of bacterial inactivation, in a near-neutral $\mathrm{pH}$ environment, were totally different. In our study, the survival rates of L. innocua suspended in buffer 7.0 under pressure reaching up to $400 \mathrm{MPa}$ for 5 min have shown no significant differences ( $\mathrm{p} \geq 0.05$ ) (Figure 3). Maximum inactivation of both strains was observed after the treatment at $400 \mathrm{MPa}$ for $10 \mathrm{~min}$ and was below $1.5 \log (\mathrm{CFU} / \mathrm{mL})$. On the contrary to our results. Patterson et al. [1995] showed $5 \log (\mathrm{CFU} / \mathrm{mL})$ reduction of $L$. monocytogenes in a phosphate buffer $(\mathrm{pH} 7)$ after the treatment at $375 \mathrm{MPa}$ for $15 \mathrm{~min}$. In another study, it has been reported that the treatment at $207 \mathrm{MPa}$ for $10 \mathrm{~min}$ at $25^{\circ} \mathrm{C}$, caused a $0.7 \log (\mathrm{CFU} / \mathrm{mL})$ reduction in population numbers of two strains of L. monocytogenes suspended in a peptone solution (pH 7.2) [Alpas et al., 2000]. Stewart et al. [1997] described the effect of HHP on the injury and destruction of two strains of L. monocytogenes (Scott A and CA) in buffer suspensions. They observed complete sterility in buffer $\mathrm{pH} 4.0$ in the case of the samples pressurized at $404 \mathrm{MPa}$ for $10 \mathrm{~min}$. However, under the same HHP conditions in buffer 6.0, both strains were reduced by $4.0 \log (\mathrm{CFU} / \mathrm{mL})$ and $6.0 \log (\mathrm{CFU} / \mathrm{mL})$, respectively. On the other hand, the number of cells of both strains decreased by $5.0 \log (\mathrm{CFU} / \mathrm{mL})$ in $\mathrm{pH} 4.0$ and by $3.0 \log$ $(\mathrm{CFU} / \mathrm{mL})$ in $\mathrm{pH} 6.0$ upon pressurization at $300 \mathrm{MPa}, 25^{\circ} \mathrm{C}$ for $10 \mathrm{~min}$ [Stewart et al., 1997].

\section{Sublethal injury to bacterial cells}

Microorganisms are said to be sublethally injured if they survive an inactivation treatment. Some of the damages might be repaired, especially while microorganisms are stored under favorable conditions [Jofré et al., 2010]. Pressure treatment at 300-600 MPa, at ambient temperature for a few minutes destroys pathogenic bacteria, such as Listeria, Escherichia, Salmonella, as well as causes sublethal injuries [Patterson et al., 1995]. However, under these conditions some bacteria are sublethally injured. This phenomenon has been confirmed in our study (Table 1). As aforementioned, survivors may re- 
TABLE 1. The level of sublethal injuries of L. innocua strains after HHP treatment.

\begin{tabular}{|c|c|c|c|c|c|c|c|c|c|}
\hline \multirow{2}{*}{$\begin{array}{l}\text { Strains/HHP } \\
\text { parameters }\end{array}$} & \multicolumn{3}{|c|}{$200 \mathrm{MPa}$} & \multicolumn{3}{|c|}{$300 \mathrm{MPa}$} & \multicolumn{3}{|c|}{$400 \mathrm{MPa}$} \\
\hline & $1 \mathrm{~min}$ & $5 \mathrm{~min}$ & $10 \min$ & $1 \mathrm{~min}$ & $5 \mathrm{~min}$ & $10 \mathrm{~min}$ & $1 \mathrm{~min}$ & $5 \mathrm{~min}$ & $10 \min$ \\
\hline \multicolumn{10}{|c|}{ Sublethal injuries in beetroot juice $(\log \mathrm{CFU} / \mathrm{mL})$} \\
\hline $\begin{array}{l}\text { Listeria innocua } \\
\text { CIP } 80.11 \mathrm{~T}\end{array}$ & $0.11 \pm 0.26^{\mathrm{a}}$ & $0.08 \pm 0.23^{\mathrm{a}}$ & $0.37 \pm 0.26^{\mathrm{a}}$ & $-0.03 \pm 0.27^{a}$ & $0.72 \pm 0.26^{\mathrm{a}}$ & $0.58 \pm 0.69^{a}$ & $\mathrm{Nd}^{\mathrm{a}}$ & $\mathrm{Nd}^{\mathrm{a}}$ & $\mathrm{Nd}^{\mathrm{a}}$ \\
\hline $\begin{array}{l}\text { Listeria innocua - wild } \\
\text { type strain } 23 / 13\end{array}$ & $-0.02 \pm 0.00^{\mathrm{a}}$ & $0.01 \pm 0.05^{\mathrm{a}}$ & $-0.09 \pm 0.09^{a}$ & $0.13 \pm 0.04^{\mathrm{a}}$ & $0.10 \pm 0.00^{\mathrm{a}}$ & $2.34 \pm 0.26^{b}$ & $0.83 \pm 0.13^{\mathrm{a}, \mathrm{b}}$ & $-0.05 \pm 1.02^{\mathrm{a}}$ & $0.01 \pm 0.17^{\mathrm{a}}$ \\
\hline \multicolumn{10}{|c|}{ Sublethal injuries in Mcllvain buffer $\mathrm{pH} 4.0(\log \mathrm{CFU} / \mathrm{mL})$} \\
\hline $\begin{array}{l}\text { Listeria innосиа } \\
\text { CIP } 80.11 \mathrm{~T}\end{array}$ & $-0.06 \pm 0.27^{\mathrm{a}}$ & $0.05 \pm 0.25^{\mathrm{a}}$ & $0.12 \pm 0.22^{\mathrm{a}}$ & $0.54 \pm 0.29^{\mathrm{a}}$ & $0.45 \pm 0.67^{\mathrm{a}}$ & $0.54 \pm 0.00^{\mathrm{a}}$ & $0.81 \pm 0.00^{\mathrm{a}}$ & $0.24 \pm 0.00^{\mathrm{a}}$ & $0.15 \pm 0.00^{\mathrm{a}}$ \\
\hline $\begin{array}{l}\text { Listeria innocua - wild } \\
\text { type strain } 23 / 13\end{array}$ & $-0.19 \pm 0.22^{\mathrm{a}}$ & $-0.09 \pm 0.24^{\mathrm{a}}$ & $0.07 \pm 0.26^{\mathrm{a}}$ & $0.42 \pm 0.39^{\mathrm{a}}$ & $0.28 \pm 0.92^{\mathrm{a}}$ & $0.45 \pm 0.21^{\mathrm{a}}$ & $0.30 \pm 0.16^{\mathrm{a}}$ & $0.30 \pm 1.01^{\mathrm{a}}$ & $0.42 \pm 0.34$ \\
\hline \multicolumn{10}{|c|}{ Sublethal injuries in McIlvain buffer pH $7.0(\log \mathrm{CFU} / \mathrm{mL})$} \\
\hline $\begin{array}{l}\text { Listeria innocua } \\
\text { CIP } 80.11 \mathrm{~T}\end{array}$ & $0.10 \pm 0.21^{\mathrm{a}}$ & $0.09 \pm 0.28^{\mathrm{a}}$ & $0.17 \pm 0.25^{\mathrm{a}}$ & $0.14 \pm 0.24^{\mathrm{a}}$ & $0.17 \pm 0.26^{\mathrm{a}}$ & $0.31 \pm 0.27^{\mathrm{a}}$ & $0.67 \pm 0.25^{\mathrm{a}, \mathrm{b}}$ & $2.64 \pm 0.34^{c}$ & $3.83 \pm 0.32^{\mathrm{c}}$ \\
\hline $\begin{array}{l}\text { Listeria innocua - wild } \\
\text { type strain } 23 / 13\end{array}$ & $0.04 \pm 0.28^{\mathrm{a}}$ & $0.08 \pm 0.20^{\mathrm{a}}$ & $-0.01 \pm 0.25^{\mathrm{a}}$ & $0.03 \pm 0.23^{\mathrm{a}}$ & $0.05 \pm 0.22^{\mathrm{a}}$ & $0.24 \pm 0.27^{\mathrm{a}}$ & $0.28 \pm 0.24^{\mathrm{a}}$ & $1.21 \pm 0.23^{b}$ & $2.39 \pm 0.25^{\circ}$ \\
\hline
\end{tabular}

All data were the mean $\pm \mathrm{SD}, \mathrm{n}=2$. Values in rows $(\mathrm{a}-\mathrm{d})$ denoted with different letter are significantly different at $\mathrm{p}<0.05$. Nd: not detected.

veal increased sensitivity to inhibitors, such as sodium chloride [Mackey, 2000]. In our study, it has been observed that the maximum level of sublethal injury occurred when the cells were suspended in buffer $\mathrm{pH} 7.0$ (Table 1) and exposed to the pressure of $400 \mathrm{MPa}$ for $10 \mathrm{~min}$. The level of sublethal injury was $3.83 \log (\mathrm{CFU} / \mathrm{mL})$ and $2.39 \log (\mathrm{CFU} / \mathrm{mL})$ for the collection strain and wild type strain, respectively. Pressure treatment at $200 \mathrm{MPa}$ and $300 \mathrm{MPa}$ in buffer $\mathrm{pH} 7.0$ caused no significant changes $(\mathrm{p} \geq 0.05)$ in the levels of sublethal injury of bacterial cells. The same observation was made in buffer $\mathrm{pH} 4.0(\mathrm{p} \geq 0.05)$ (Table 1). In turn, beetroot juice samples exposure to $300 \mathrm{MPa}$ for 10 min significantly $(\mathrm{p}<0.05)$ affected the level of sublethal injury of the wild type strain compared with the collection strain (Table 1). Sokolowska et al. [2014] confirmed that the pressure of $400 \mathrm{MPa}$ triggered sublethal injury of $E$. coli cells in PBS. After 5 and $10 \mathrm{~min}$ of HHP treatment, $2.4 \log (\mathrm{CFU} / \mathrm{mL})$ and $2.7 \log (\mathrm{CFU} /$ $\mathrm{mL}$ ) of sublethally injured cells were observed, while in beetroot juice the counts of injured cells reached $1.5 \log (\mathrm{CFU} /$ $\mathrm{mL})$ and $0.8 \log (\mathrm{CFU} / \mathrm{mL})$, respectively. On the other hand, the application of $400 \mathrm{MPa}$ for $10 \mathrm{~min}$ on five strains of L. monocytogenes suspended in a complex medium caused that the number of sublethally injured cells in population was less than $1 \log (\mathrm{CFU} / \mathrm{mL})$ [Jofré et al., 2010]. The number of sublethally injured survivors in the population depends on high pressure treatment parameters, as well as on the type of microbiota and medium. In some cases, the level of sublethally injured cells might be almost $100 \%$. The adequate identification and quantification of the sublethally injured population plays an important role in food safety.

\section{TEM observations}

The character of sublethal injuries of $L$. innocua triggered by high hydrostatic pressure, was illustrated by TEM microscopy. Changes in L. innocua cells morphology are shown in Figure 4. TEM images of untreated samples demonstrated intact, characteristic rod-shaped L. innocua cells, single or dividing. Cell membrane and walls were clearly defined with centrally located genome surrounded by the integrated cytoplasmic area and tickly packed ribosomes (Figure 4 a,b). The mechanisms of microbial inactivation by HHP have been mostly associated with the damage of cell membrane, as the major target of pressure treatment. Loss of membrane integrity and swelling leads to the leakage of cellular materials and nucleoid condensation [Hauben et al., 1996; Mañas \& Mackey, 2004]. According to plate count results, the reduction of both strains suspended in buffer $\mathrm{pH} 7.0$ after HHP treatment at $400 \mathrm{MPa}$ for $5 \mathrm{~min}$ was less than $1 \mathrm{log}(\mathrm{CFU} /$ $\mathrm{mL})$. The level of sublethal injury was $2.64 \log (\mathrm{CFU} / \mathrm{mL})$ and $1.21 \log (\mathrm{CFU} / \mathrm{mL})$ for collection and wild type $L$. innocua strain, respectively (Figure 3 ). It was coherent with the results which we achieved using the transmission electron microscopy technique. Most of the cells in the population observed by TEM had an intact cell membrane. Only a few cells of L. innocua wild type strain have presented surface damage (Figure $4 \mathrm{f}$ ). TEM observations confirmed aggregation of cytoplasm. Disorganization of the genome area containing fibrillar regions was observed in all populations of both strains (Figure $4 \mathrm{c}, \mathrm{d}, \mathrm{e}, \mathrm{f}$ ). Alterations in the appearance of the interior of the Escherichia coli cells were reported after HHP treatment at 300 and $600 \mathrm{MPa}$ for $5 \mathrm{~min}$ [Prieto-Calvo et al., 2014] and of Listeria monocytogenes cells interior after the treatment at $450 \mathrm{MPa}$ for $5 \mathrm{~min}$ [Huang et al., 2015]. Monitoring of the cellular ultrastructure by TEM showed the cellular enlargement, disruption of cellular membranes, condensation of the cytoplasmic material and disorganization of the genome area [Huang et al., 2015; PrietoCalvo et al., 2014]. Mackey et al. [1994] observed that cells of L. monocytogenes treated under $250 \mathrm{MPa}$ were characterized with unusual symmetrical areas in the cytoplasm. These changes were related to the deprivation of ribosomes, resembling gas bubbles, which could have been due to the osmotic effects or phase changes in the membrane. Under the same treatment conditions, amorphous compacted regions were 


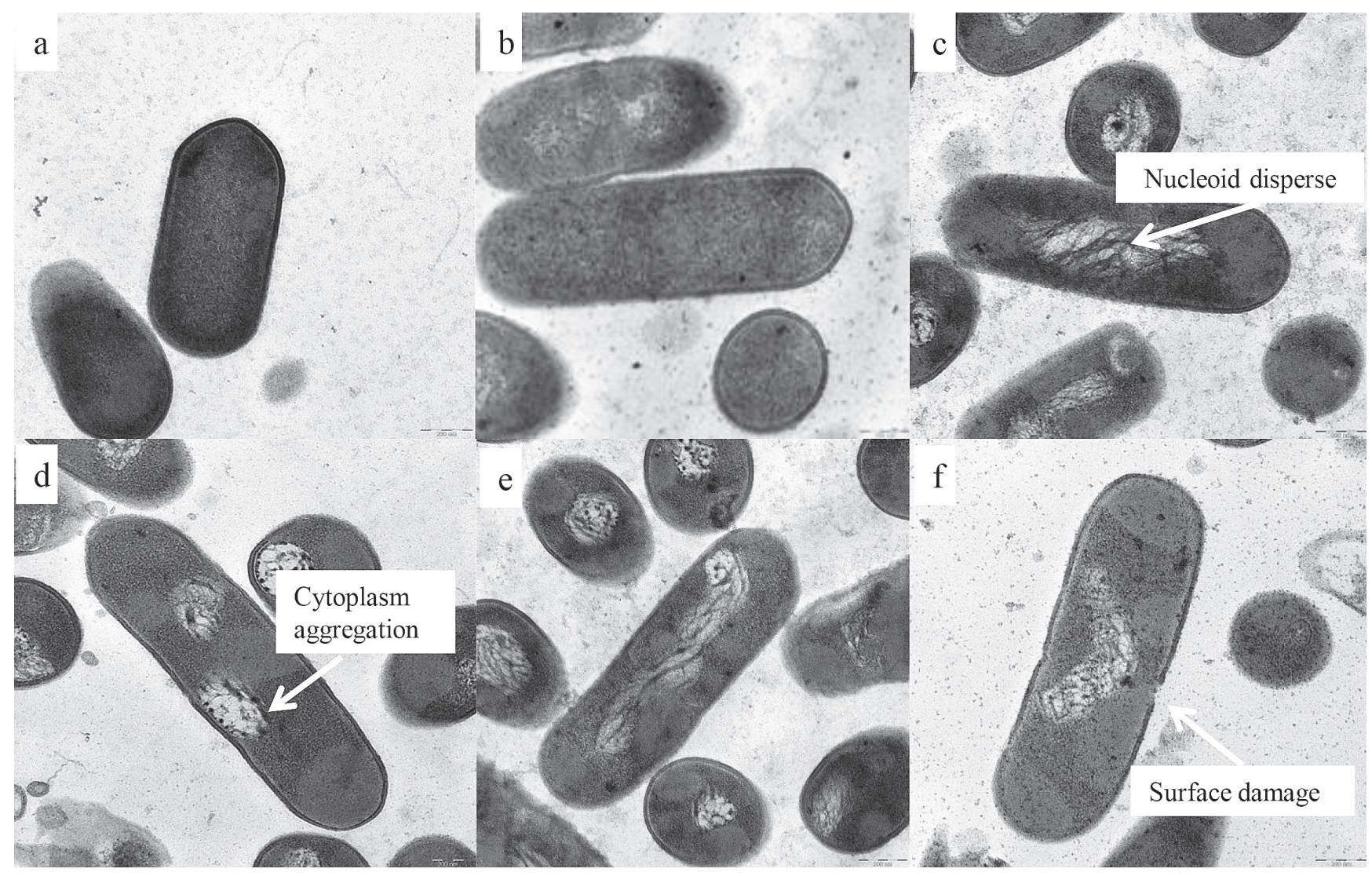

FIGURE 4. TEM images of untreated L. innocua strains (a) CIP80.11T and (b) wild type strain 23/2013 and after exposure to $400 \mathrm{MPa}$ for $5 \mathrm{~min}$ (c-d) and (e-f) respectively. Scale bar, $200 \mathrm{~nm}$. Representative images of the samples are shown.

noticed in Salmonella Thompson. It was probably induced by denaturation of cytoplasmic protein [Mackey et al., 1994]. Increased pressure up to $500 \mathrm{MPa}$ resulted in extreme condensation of the cytoplasm, whilst the outline of the cells was intact [Mackey et al., 1994].

\section{Variation in resistance to HHP}

Numerous studies have demonstrated that variations in the resistance of microorganisms to high pressure occurred not only among the different species of bacteria, but also among the strains belonging to the same species [Alpas et al., 1999; Jordan et al., 2001; Boeijen et al., 2010; Huang et al., 2015]. It has been reported that some bacterial strains with very high pressure resistance were isolated from the natural environment. Because of biodiversity of microorganisms, the results that were obtained in different studies varied significantly [Alpas et al., 2000]. The studies that we have conducted on Listeria, which was suspended in beetroot juice, showed a certain phenomenon. The collection strain was easier to inactivate than the strain isolated from the natural environment (Figure 1). Moreover, the wild type strain was not completely inactivated in an acidic medium, even being treated in a very harsh way (Figure 2). Alpas et al. [1999] studied the variation in pressure resistance among nine strains of $L$. monocytogenes. They observed that after pressure treatment at $345 \mathrm{MPa}$ for $5 \mathrm{~min}$ at $25^{\circ} \mathrm{C}$, some strains were more resistant to pressure than others. The viability loss of cells ranged from 0.9 to $3.5 \log (\mathrm{CFU} / \mathrm{mL})$. In another work, all the survivors of two strains of L. mono- cytogenes suspended in a peptone solution were completely injured after being exposed to the aforementioned factors. The diversity between 24 piezotolerant variants of L. monocytogenes, which were resistant to pressure treatment at $350 \mathrm{MPa}$ was examined by Boeijen et al. [2010]. Those 24 strains were compared with the wild type strain. In most cases the wild type strain revealed greater sensitivity than the used variants. Most of them were also resistant to other stresses besides HHP, such as high temperature and low $\mathrm{pH}$. Differences among the variants were observed in e.g. acid resistance, growth rate or motility. The authors suggested that this population diversity may be essential to the persistence of pathogens such as L. monocytogenes in a range of environments [Boeijen et al., 2010].

\section{CONCLUSIONS}

It has been confirmed in our study that high pressure can result in the loss of viability of L. innocua cells. It was found that the level of reduction by HHP treatment at $20^{\circ} \mathrm{C}$ in beetroot juice and buffer solutions was strictly dependent on a couple of factors, including: the pressure applied, the duration of the process, as well as the origin of the strain. In spite of the fact that the $\mathrm{pH}$ of both media was similar, the survivability of both strains was greater in beetroot juice than in the buffer. It can be explained by the content of organic compounds which are known to be able to produce a protective layer for bacterial cells which could inhibit the effect of pressure treatment. 
On an industrial scale, juices are exposed to pressures of $300-600 \mathrm{MPa}$ for a few minutes at $20^{\circ} \mathrm{C}$ or below. This environment is sufficient to reduce the number of spoilage microorganisms such as: yeast, moulds, and lactic acid bacteria. However, the results of this study have proved that the mentioned above factors are not always sufficient enough to inactivate pathogens and ensure consumer safety.

To attain safe standards of high pressure processed foods, particular attention should be paid to the potential presence of sublethal injured cells. Moreover, baroresistance among microbial species and strains should also be taken into consideration. The conditions of pressure processing should be properly selected for the type of product as well as the expected conditions and duration of storage. It should be particularly taken into account that the possibility of recovery of sublethally injured cells may occur. Therefore, it is worth considering the coupling of HHP and other treatments to ensure microbiological stability and health safety of juices and beverages from beetroots or other root vegetables.

\section{RESEARCH FUNDING}

This work was funded from statutory funds of prof. Wacław Dąbrowski Institute of Agricultural and Food Biotechnology, Warsaw, Poland.

\section{CONFLICT OF INTEREST}

Authors declare no conflict of interest.

\section{REFERENCES}

1. Alpas, H., Kalchayanand, N., Bozoglu, F., Ray, B. (2000). Interactions of high hydrostatic pressure, pressurization temperature and $\mathrm{pH}$ on death and injury of pressure - resistant and pressure - sensitive strains of foodborne pathogens. International Journal of Food Microbiology, 60, 33-42.

2. Alpas, H., Kalchayanand, N., Bozoglu, F., Sikes, A., Dunne, C.P. (1999). Variation in resistance to hydrostatic pressure among strains of food - borne pathogens. Applied and Environmental Microbiology, 65(9), 4248-4251.

3. Boeijen, I.K.H. van, Chavaroche, A.A.E., Valderrama, W.B., Moezelaar, R., Zweitering, M.H., Abee, T. (2010). Population diversity of Listeria monocytogenes LO28: phenotypic and genotypic characterization of variants resistant to high hydrostatic pressure. Applied and Environmental Microbiology, 76(7), 2225-2233.

4. Clifford, T., Howatson, G., West, D.J., Stevenson, E.J. (2015). The potential benefits of red beetroot supplementation in health and disease. Nutrients, 7(4), 2801-2822

5. Commission Regulation (EC) No 2073/2005 of 15 November 2005 on microbiological criteria for foodstuffs

6. Escolar, C., Gómez, D., Ruiz-Garcia, M.D.R., Conchello, P., Herrera, A. (2017) Antimicrobial resistance profiles of Listeria monocytogenes and Listeria innocua isolated from ready-to-eat products of animal origin in Spain. Foodborne Pathogens and Diseases, 14(6), 357-363.

7. Espina, L., Garcia-Gonzalo, D., Pagan, R. (2016). Detection of thermal sublethal injury in Escherichia coli via the selective medium plating technique: mechanisms and improvements. Frontiers in Microbiology, 7, art. no. 1376.

8. Goulet, V., Hedberg, C., Le Monnier, A., de Valk, H. (2008). Increasing incidence of listeriosis in France and other European countries. Emerging Infectious Diseases, 14(5), 734 - 740.

9. Hauben, K.J.A., Bartlett, D.H., Soontjens, C.C.F., Cornelis, K., Wuytack, E.Y., Michiels, C.W. (1997). Escherichia coli mutants resistant to inactivation by high hydrostatic pressure. Applied and Environmental Microbiology, 63(3), 945-950.

10. Hoover, D.G., Metrick, C., Papineau, A.M., Farkas, D.F., Knorr, D. (1989). Biological effects of high hydrostatic pressure on food microorganisms. Food Technology, 43(3), 99-107.

11. Huang, H.W., Lung, H.M., Chang, Y.H., Yang, B.B., Wang, Ch.Y. (2015). Inactivation of pathogenic Listeria monocytogenes in raw milk by high hydrostatic pressure. Foodborne Pathogens and Diseases, 12(2), 139-144.

12. Jofré, A., Aymerich, T., Bover-Cid, S., Garriga, M. (2010). Inactivation and recovery of Listeria monocytogenes, Salmonella enterica and Staphylococcus aureus after high hydrostatic treatments up to $900 \mathrm{MPa}$. International Microbiology, 13(3), 105-112.

13. Jordan, S.L., Pascual, C., Bracey, E., Mackey, B.M. (2001). Inactivation and injury of pressure - resistant strains of Escherichia coli $\mathrm{O} 157$ and Listeria monocytogenes in fruit juice. Journal of Applied Microbiology, 91 (3), 463-469.

14. Mackey, B.M., Forestière, K., Issaacs, N.S., Stenning, R., Brooker, B. (1994). The effect of high hydrostatic pressure on Salmonella thompson and Listeria monocytogenes examined by electron microscopy. Letters in Applied Microbiology, 19(6), 429-432.

15. Mackey. B.M., Injured bacteria (2000). In B.M. Lund, T.C. Baird-Parker, G.W. Gould (eds). The Microbial Safety and Quality of Food, vol. 1. Aspen Publisher Inc., Gaithersburg, Maryland, USA, pp. 315-341.

16. Mañas, P., Mackey, B.M. (2004). Morphological and physiological changes induced by high hydrostatic pressure in exponential and stationary phase cells of Escherichia coli: relationship with cell death. Applied and Environmental Microbiology, 70(3), 1545-1554.

17. Patterson, M.F, Quinn, M., Simpson, R., Gilmour, A. (1995). Sensitivity of vegetative pathogens to high hydrostatic pressure treatments in phosphate - buffered saline and foods. Journal of Food Protection, 58(5), 524-529.

18. Prieto-Calvo, M., Prieto, M, Lopez, M., Alvarez-Ordóñez, A. (2014). Effects of high hydrostatic pressure on Escherichia coli ultrastructure, membrane integrity and molecular composition as assessed by FTIR spectroscopy and microscopic imaging techniques. Molecules, 19, 21310-21323.

19. Reynolds, E.S. (1963). The use of lead citrate at high $\mathrm{pH}$ as electron-opaque stain for electron microscopy. Journal of Cell Biology, 17, 208-213.

20. Sapers, G.M. (2003). Washing and sanitizing raw materials for minimally processed fruit and vegetable products. In J.S. Novak, G. M. Sapers, V.K. Juneja (eds.). Microbial Safety of Minimally Processed Foods. CRC Press, Boca Raton, Florida, USA, pp. 221-253.

21. Sokołowska, B., Woźniak, Ł., Skąpska, S., Porębska, I., Nasiłowska, J., Rzoska, S.J. (2017). Evaluation of quality changes of beetroot juice after high hydrostatic pressure processing. High Pressure Research, 37(2), 214-222. 
22. Sokołowska, B., Skąpska, S., Niezgoda, J., Rutkowska, M., Dekowska, A., Rzoska, S.J. (2014). Inactivation and sublethal injury of Escherichia coli and Listeria innocua by high hydrostatic pressure in model suspensions and beetroot juice. High Pressure Research, 34(1), 147-155.

23. Sokołowska, B., Skąpska, S., Fonberg-Broczek, M., Niezgoda, J., Rutkowska, M., Chotkiewicz, M., Dekowska, A., Rzoska, S.J. (2013). The effect of high hydrostatic pressure on the survival of Sacharomyces cerevisiae in model suspensions and beetroot juice. High Pressure Research 33(1), 165-171.

24. Sokołowska, B., Chotkiewicz, M., Niezgoda, J., Dekowska, A. (2011). Evaluation of microbial contamination of commercially available unpasteurized, freshly squeezed fruity and vegetable juice. Zeszyty Problemowe Postępów Nauk Rolniczych, 569, 219 -228 (in Polish; English abstract).

25. Stewart, C.M., Jewett, F.F., Dunne, C.P., Hoover, D.G. (1997) Effect of concurrent high hydrostatic pressure, acidity and heat on the injury and destruction of Listeria monocytogenes. Journal of Food Safety, 17(1), 23-36.

26. USDA Food Composition Databases [https://ndb.nal.usda.gov/ ndb/search/list_28.02.2018].
27. Wang, C.Y., Huang, H.W., Hsu, C.P., Yang, B.B. (2016). Recent advances in food processing using high hydrostatic pressure technology. Critical Reviews in Food Science and Nutrition, 56(4), 527-540.

28. Wesche, A.M., Gurtler, J.B., Marks, B.P., Ryser, E.T. (2009). Stress, sublethal injury, resuscitation and virulence of bacterial foodborne pathogens. Journal of Food Protection, 72 (5), 1121-1138.

29. Yang, B.W., Shi, Y., Xia, X.D., Xi, M.L., Wang, X., Ji, B.Y., Meng, J.H. (2012). Inactivation of foodborne pathogens in raw milk using high hydrostatic pressure. Food Control, 28(2), 273-278

30. Yuste, J., Capellas, M., Fung, D.Y.C., Mor-Mur, M. (2004). Inactivation and sublethal injury of foodborne pathogens by high pressure processing: Evaluation with conventional media and thin agar layer method. Food Research International, 37(9), $861-866$.

31. Zielińska-Przyjemska, M, Olejnik, A., Dobrowolska-Zachwieja, A., Grajek, W. (2009). In vitro effects of beetroot juice and chips on oxidative metabolism and apoptosis in neutrophils from obese individuals. Phytotherapy Research, 23(1), 49-55.

Submitted: 1 March 2018. Revised: 17 July 2018. Accepted: 17 October 2018. Published on-line: 22 January 2019. 